\title{
Introduction to Some Indigenous Vegetables in Japan
}

\author{
Yukihiro Fujime ${ }^{1,2,3}$ \\ Faculty of Agriculture, Kyoto Prefectural University, Shimogamo, Sakyo, Kyoto, Japan 606-8522 \\ Additional index words. allium, classification, daikon, indigenous vegetable, Japan, variation
}

\begin{abstract}
Although Japan has a clear change of the seasons, the winter is mild, because it is surrounded by the sea. Even if it snows in the coastal area of the Japan Sea in the winter, it does not snow so heavily in the Pacific Ocean area. Because there is much rain in the summer and the air temperature and relative humidity are high, many horticultural crops are grown in the cool upland region, including the Hokkaido area. The Japanese islands are long from south to north covering north latitude $24^{\circ}$ and $46^{\circ}$. Many indigenous vegetables such as water dropwort, japanese hornwort, wasabi, japanese butterbur, rakkyo, chinese chive, asatsuki, goldband lily, mioga ginger, and japanese pepper as well have been grown throughout $\approx 2000$ years, being domesticated under selections and are now in modern Japan popular and important vegetables. Many variations have been produced under different climatic as well as soil conditions. Daikon, turnip, japanese bunching onion, komatsuna, kyona, taro, and eggplant have many variations in the growing areas. A lot of varieties are found particularly in daikon and turnip whose shape and color include small round, large round, long, and conical and white, green, and red, etc. Kyona and komatsuna belong to the same species, Brassica rapa, and also there are many useful variations as leaf vegetables in this species. Japanese bunching onion as an example has also many variations and in east Japan, the leaf sheaths are etiolated by hilling with soil during the winter and etiolated leaf sheaths are harvested in the spring, whereas in west Japan, the leaf sheaths are grown without hilling and green leaves are harvested. Those variations from indigenous vegetables are selected under every condition and various cultural methods were developed in growing areas. People have devised ways also how of cooking and using them depending on their eating habits as an established food culture.
\end{abstract}

There are many indigenous vegetables in Japan. Japan is an island nation and has many vegetables transferred from tropical Asia with ancient origin. The geographic situation of Japan is complex with the presence of high mountainous zones on the coastal area. The difference of latitude is also great enough from Okinawa to Hokkaido. Moreover, there is also a mountainous area in the central part of the Japanese islands. The climate is greatly different between the Pacific Ocean side and the Japan Sea side. Because various vegetables have been grown with a long history, considerable variations are accumulated in the form and growth pattern. There are some references on the leaf, fruit, and root of Japanese vegetables (Aoba, 1982, 1983) and on traditional vegetables (Takashima, 1982, 2003). To popularize the Japanese traditional vegetables in the world, descriptions should be written in English. The English descriptions concerning physiological and ecological characteristics of these vegetables are not enough (Organizing Committee of JSHS, 1994). The following is an introduction to the indigenous vegetables in Japan.

\section{LAND, NATURAL CONDITIONS, AND CLIMATES OF JAPAN}

The Japanese islands are long from south to north between north latitude $24^{\circ}$ and $46^{\circ}$. Most of the land is covered with mountains

Received for publication 13 Dec. 2011. Accepted for publication 6 Feb. 2012.

This paper was part of the workshop "Asia's Indigenous Horticultural Crops" held 26 July 2009 at the ASHS Conference, St. Louis, MO, and sponsored by the Working Group of Asian Horticulture (WGAH).

I thank Dr. Eishi Nakamura for his helpful reviews of the manuscript.

${ }^{1}$ Retired from Kyoto Prefectural University.

${ }^{2}$ Current address: 35-602, Kitatenjinmoimachi, Kinugasa, Kita, Kyoto, Japan 603-8376.

${ }^{3}$ To whom reprint requests should be addressed; e-mailyfujime@rio.odn.ne.jp.
$(62 \%)$, hills $(11.8 \%)$, plateaus $(11 \%)$, and low ground (13.8\%). Although Japan has a clear shift of the seasons, the winter is mild because it is surrounded by the sea. Although it snows much in the coastal area of the Japan Sea side in the winter, it is often fine in the Pacific Ocean coastal side. Because there is a lot of rain in the summer (1467 mm annual rainfall in Tokyo) and both the air temperature and relative humidity are high in Japan $\left(31.7{ }^{\circ} \mathrm{C}\right.$ maximum mean temperature in August in Tokyo), many horticultural crops are grown in the cool upland region, including the Hokkaido area. A winter day is defined by the daily minimum temperature being lower than $0{ }^{\circ} \mathrm{C}$. Winter days of Sapporo, Aomori, and Niigata in the area of the Japan Sea side are 135,117 , and $51 \mathrm{~d}$, respectively. On the other hand, winter days of Tokyo, Kochi, and Kagoshima on the Pacific Ocean side are 20,36 , and $17 \mathrm{~d}$, respectively. A day when the daily maximum temperature is $25^{\circ} \mathrm{C}$ or

higher is defined as a summer day. Summer days of Sapporo, Aomori, and Niigata are 46, 57 , and $88 \mathrm{~d}$, respectively. On the other hand, summer days of Tokyo, Kochi, and Kagoshima are 105,138 , and $151 \mathrm{~d}$, respectively.

\section{INDIGENOUS VEGETABLES: KIND AND CHARACTER}

Many indigenous vegetables (Table 1) such as water dropwort, japanese hornwort, wasabi, japanese butterbur, rakkyo, chinese chive, asatsuki, goldband lily, mioga ginger, and japanese pepper have been grown since $\approx 2000$ years ago (Table 2 ). Some vegetables have been introduced to Japan from east and south Asia and have been grown since the dawn of the history of Japan. These vegetables have been domesticated through selection and are still today important vegetables. Many variations have been established under different climatic and soil conditions, whereas these

Table 1. Classification and names of vegetables indigenous to Japan.

\begin{tabular}{|c|c|c|}
\hline Family & Indigenous & Variations established in Japan \\
\hline Cruciferae & (wasabi) Wasabia japonica & $\begin{array}{l}\text { (daikon) Raphanus sativus L. daikon group } \\
\text { (turnip) Brassica rapa L. rapifera group } \\
\text { (komatsuna) Brassica rapa } \\
\text { L. perviridis group } \\
\text { (mizuna, mibuna) Brassica rapa } \\
\text { L. japonica group }\end{array}$ \\
\hline Liliaceae & $\begin{array}{l}\text { (rakkyo) Allium chinense } \\
\text { (chinese chive) Allium tuberosum } \\
\text { (asatsuki) Allium schoenoprasum } \\
\text { L. var. foliosum Regel } \\
\text { (goldband lily) Lilium auratum }\end{array}$ & $\begin{array}{l}\text { (japanese bunching onion) } \\
\text { Allium fistulosum } \\
\text { (wakegi) Allium } \times \text { wakegi }\end{array}$ \\
\hline Compositae & $\begin{array}{l}\text { (japanese butterbur) } \\
\text { Petasites japonicus }\end{array}$ & \\
\hline $\begin{array}{l}\text { Araceae } \\
\text { Solanaceae }\end{array}$ & & $\begin{array}{l}\text { (taro) Colocasia esculenta } \\
\text { (eggplant) Solanum melongena }\end{array}$ \\
\hline Umbelliferae & $\begin{array}{l}\text { (water dropwort) Oenanthe javanica } \\
\text { (japanese hornwort) Cryptotaenia } \\
\text { canadensis DC. subsp. japonica }\end{array}$ & \\
\hline Zingiberaceae & (mioga ginger) Zingiber mioga & \\
\hline Rutaceae & $\begin{array}{l}\text { (japanese pepper) } \\
\text { Zanthoxylum piperitum }\end{array}$ & \\
\hline
\end{tabular}


vegetables have been cultivated. There are some minor indigenous vegetables such as udo, water shield, water chestnut, and edible amaranthus. The comments on those minor vegetables were omitted here. The classification and scientific names were from the description of the Japanese Society for Horticultural Science (Jap. Soc. Hort. Sci., 2005).

Water dropwort, seri in Japanese (Oenanthe japonica DC). These are aquatic, herbaceous perennial plants that are found wild in wet places throughout Japan (Fig. 1). In the fall and the winter, it produces a lot of radical leaves, which are the object of harvesting. Its use is similar to watercress (cruciferae). This fresh green has a fragrant smell. It bears many stolons in the spring and summer and bolts and flowers in the midsummer. It is propagated by stolons.

Japanese hornwort, mitsuba in Japanese (Cryptotaenia canadensis DC. subsp. japonica Hand.). This is a herbaceous perennial plant whose aboveground part is damaged by frost in the winter. It is propagated by seeds. A rootmitsuba and a cut-mitsuba are blanched by hilling and a string-mitsuba is cultivated in hydroponic conditions without blanching.

Wasabi, wasabi in Japanese (Wasabia japonica Matsum.). Wasabi is an aquatic perennial plant, which grows wild in the streams of mountains throughout Japan. Wasabi is grown for its rhizomes, which are used as a condiment. It is normally propagated by offsets. Whole plants have the flavor and could be used. Wasabi is a cool-season crop and needs shading from the strong sunshine during the summer months. Its production is confined to regions where water temperature is preferred at $\approx 10$ to $15^{\circ} \mathrm{C}$ throughout the year.

Japanese butterbur, fuki in Japanese (Petasites japonicus Maxim.). Japanese butterbur is a perennial herbaceous and dioecious plant. The petioles are mainly used. The blade and flower buds are also used. It bears three to four long, thin rhizomes, and the rhizome develops several big leaves with long petioles. Japanese butterbur grows vigorously in the spring and fall but the leaves die back in the winter. Akita-fuki (Petasites japonicus ssp. giganteus Kitam.) is native to the cool regions of Japan whose leaf is huge, developing a petiole $2 \mathrm{~m}$ long and a blade $1.5 \mathrm{~m}$ in diameter.

Rakkyo, rakkyo in Japanese (Allium chinense G. Don). Rakkyo is perennial and tillers vigorously. Each shoot forms a small bulb ( 2 to $5 \mathrm{~cm}$ long) at the base. One bulb multiplies into six to nine (large-bulb type) or 10 to 15 (multiple-bulb type) bulblets in a year. It is propagated from bulbs (Table 3). Bulb formation is promoted by long days in the spring, and in the summer, the plant becomes semidormant, the leaves being withered. It is blanched for softening tissue and moderating smell. Growth and development are late compared with other alliums.

Chinese chive, nira in Japanese (Allium tuberosum Rottler ex Spreng.). Chinese chive is a perennial plant and has vigorous branches on rhizomes. The green leaves are mainly used, but flower buds and scapes are also

Table 2. Historical records of vegetable cultivation in Japan.

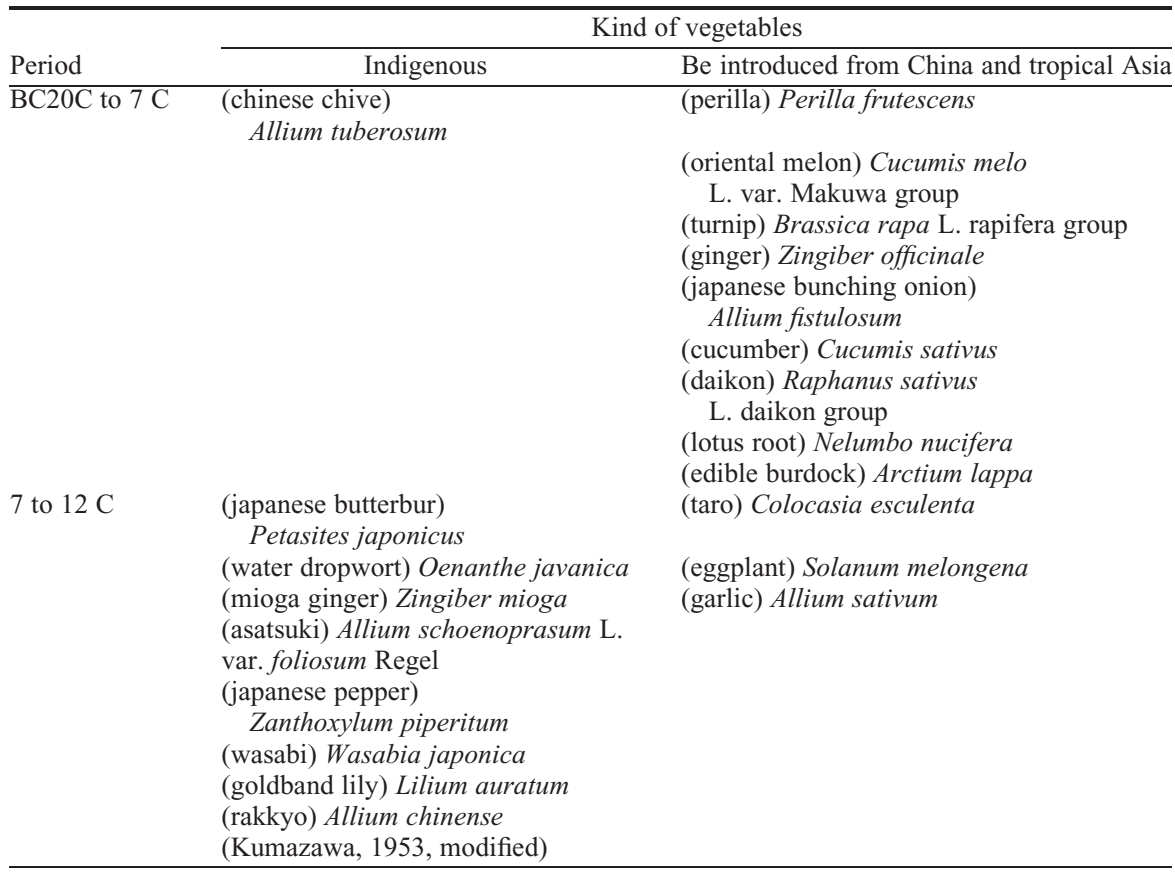
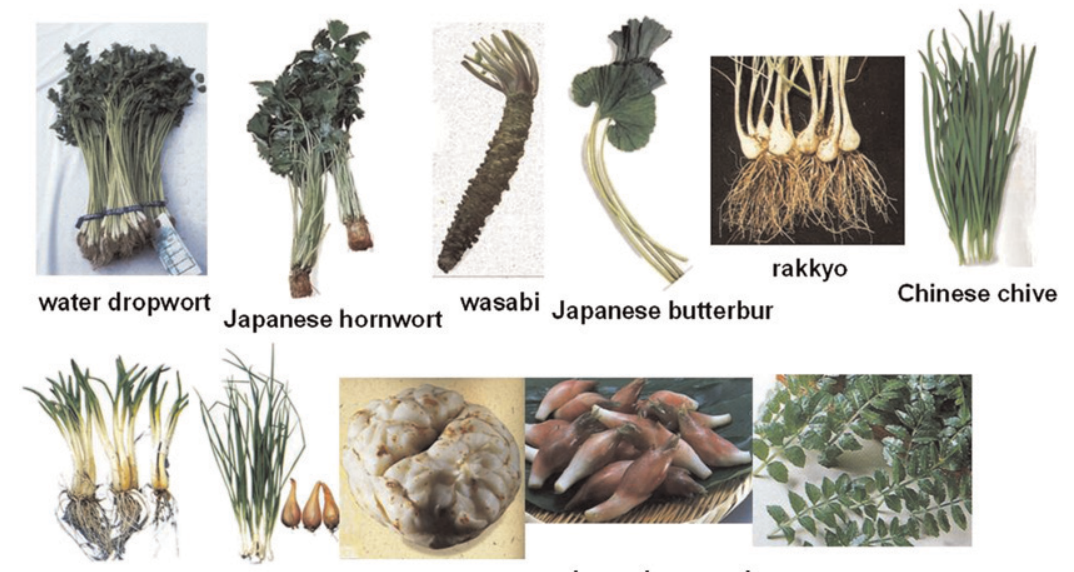
Japanese hornwort

Japanese butterbur

Chinese chive

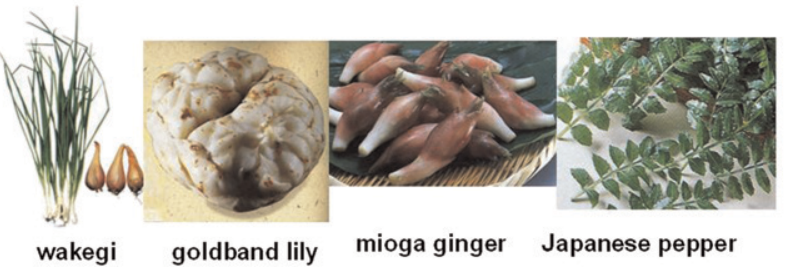

Fig. 1. Indigenous vegetables of Japan.

Table 3. Comparison of growth and development in allium crops.

\begin{tabular}{|c|c|c|c|c|c|c|c|c|}
\hline & Spring & Summer & Fall & Winter & Stem & Leaf & Propagation & Dormancy \\
\hline Wakegi & $\mathrm{P}$ & $\mathrm{HB}$ & & & Hollow & Round & Bulbs & Summer \\
\hline Rakkyo & $\mathrm{H}$ & P B & $\mathrm{F}$ & & & Round & Bulbs & Summer \\
\hline Chinese chive & $\mathrm{PH}$ & $\mathrm{F}$ & $\mathrm{H}$ & $\mathrm{P}$ & & Flat & Seeds & Winter \\
\hline Asatsuki & $\mathrm{BF}$ & $\mathrm{P}$ & & & Hollow & Round & Bulbs & Summer \\
\hline $\begin{array}{l}\text { Japanese } \\
\text { bunching onion }\end{array}$ & $\mathrm{P}$ & & $\mathrm{H}$ & $\mathrm{H}$ & Hollow & Round & Seeds & Winter \\
\hline Onion & $\mathrm{H}$ & & $\mathrm{P}$ & & Hollow & Round & Seeds & Summer \\
\hline
\end{tabular}

$\mathrm{B}=$ bulb; $\mathrm{F}=$ flower; $\mathrm{H}=$ harvest; $\mathrm{P}=$ planting/sowing.

used. Blanched and etiolated leaves are occasionally used. Chinese chive is usually propagated by seeds in commercial propagation and is also propagated by dividing the clumps.

Asatsuki in Japanese, a variety of chive (Allium schoenoprasum L. var. foliosum Regel). Asatsuki is planted in late summer and harvested in winter or spring (Table 3 ). The stem is hollow and the leaf is round.
Asatsuki has no seeds but produces bulbs. Bulbs are formed in early summer and enter into dormancy after flowering.

Goldband lily, yurine in Japanese (Lilium auratum Lindl.). Goldband lily is an ornamental plant and bulbs are harvested from November to February. It has a slightly bitter and sweet taste and the texture is similar to potato/globe artichoke. It can be propagated 
by scaling and bulblets. Each clove is separated and cooked for chawan-mushi (steamed egg custard). Ginkgo-nuts (Ginkgo biloba L.) are also used for chawan-mushi.

Mioga ginger, myoga in Japanese (Zingiber mioga Roscoe). In Japan mioga ginger is found growing wild in semishady places in the mountainous area. Mioga ginger is grown for its young inflorescences and young shoots, which are used as a condiment. It is a perennial plant, growing 40 to $100 \mathrm{~cm}$ high. Because the flowers rarely set seeds, mioga is propagated by the underground stems. The plant is killed by frost, but the underground stems are hardy to cold. The optimum temperature for growing is 20 to $30^{\circ} \mathrm{C}$. Young inflorescence production is achieved by planting rhizomes toward the end of March. Harvesting is carried out from July to late October. Blanched shoots are obtained by growing mioga ginger in underground pits. The plant is lifted late fall up to early winter and replanted in blanching beds kept warm by compost or an electric cable. The plants are exposed to the light shortly before harvesting to make them reddish-tinged.

Japanese pepper, sansho in Japanese (Zanthoxylum piperitum $D C$.). Japanese pepper is a dioecious shrub $3 \mathrm{~m}$ high. Branches have thorns, 5 to $10 \mathrm{~mm}$ long. It grows wild in the hills and mountains all over Japan. Flower buds are formed at the end of branches and yellowish green flowers bloom in April to May. Fruits are green in the summer and the ripened fruits turn to reddish brown in September. It is propagated by seeds or grafting. Young leaves, flowers, and fruits are harvested and are used as condiments.

\section{SPREAD OF INTRODUCED VEGETABLES IN JAPAN}

Many variations of shape and characters in vegetables have been established while they have been cultivated under different climatic (hot/cool/cold) and soil conditions (sand/clay/ loam). As the Japanese welcome the coming of new seasons, early-season cultivars have been selected and earlier harvests have been preferred. Because people consume vegetables mainly just after harvest, their freshness and high quality are naturally most evaluated. Because they use almost every plant part such as sprouts, stems, leaves, flowers, seeds, fruits, and roots, different characters of shape, color, smell, and texture have been selected and propagated (for example, root of edible burdock, subterranean root of louts, bulbs of goldband lily, and gingko fruits). Daikon, turnip, japanese bunching onion, kyona, taro, and eggplant have especially been selected with many variations at different cultivation areas. Almost of these vegetables had been introduced to Japan until $12 \mathrm{C}$ but komatsuna and kyona have been established well in Japan.

Daikon, daikon in Japanese, Raphanus sativus L. daikon group. Daikon is one of the major vegetables in production and planting area in Japan (Table 4). Although it differs with respect to the size, shape, color, and quality depending on the cultivars (Fig. 2), the chromosome number in all daikons is identical $(n=9)$. Some shapes are round $(2 \mathrm{~kg})$, huge round (15 to $30 \mathrm{~kg})$, or very long $(1.5 \mathrm{~m}$ long) and neck colors are white and green. Some curve at the neck.

Turnip, kabu in Japanese, Brassica rapa L. rapifera group. White oriental types are cultivated in the western part of Japan and colored oriental types are grown along the coastal area of the Japan Sea (Fig. 3).

Table 4. Vegetable production in Japan (2006).

\begin{tabular}{lcrr}
\hline Vegetable & Planted area (ha) & Production (t) & \multicolumn{1}{c}{ Ship (t) } \\
\hline Total & 505,500 & $14,324,000$ & $11,752,000$ \\
Root vegetable & 184,800 & $5,645,000$ & $4,502,000$ \\
Daikon & 38,300 & $1,650,000$ & $1,264,000$ \\
Turnip & 5,390 & 150,700 & 119,800 \\
Taro & 14,400 & 174,700 & 102,700 \\
Leaf and stem vegetable & 179,200 & $5,320,000$ & $4,475,000$ \\
Komatsuna & 5,650 & 90,800 & 74,800 \\
Japanese butterbur & 690 & 16,900 & 13,700 \\
Japanese hornwort & 1,240 & 18,400 & 17,200 \\
Japanese bunching onion & 22,700 & 491,900 & 378,800 \\
Chinese chive & 2,200 & 62,700 & 56,000 \\
Fruit vegetable & 110,100 & $2,495,000$ & $2,021,000$ \\
Eggplant & 11,100 & 371,900 & 275,200 \\
\hline Agin
\end{tabular}

Agriculture \& Livestock Industries, 2006.

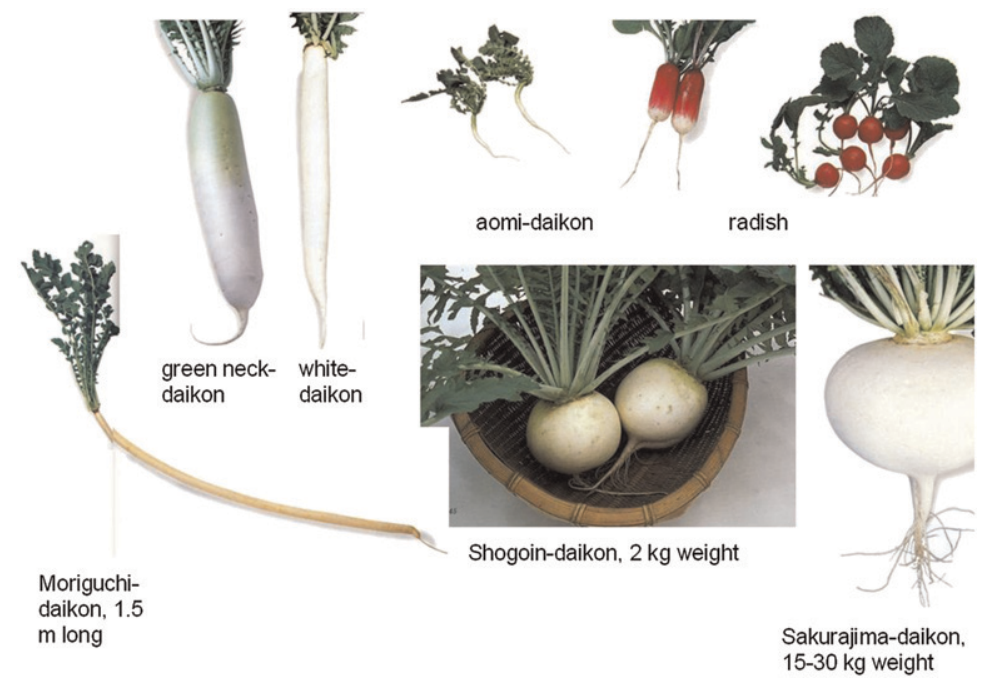

Fig. 2. Classification of daikon by shape. (Vegetable supply stabilization fund, 1997).

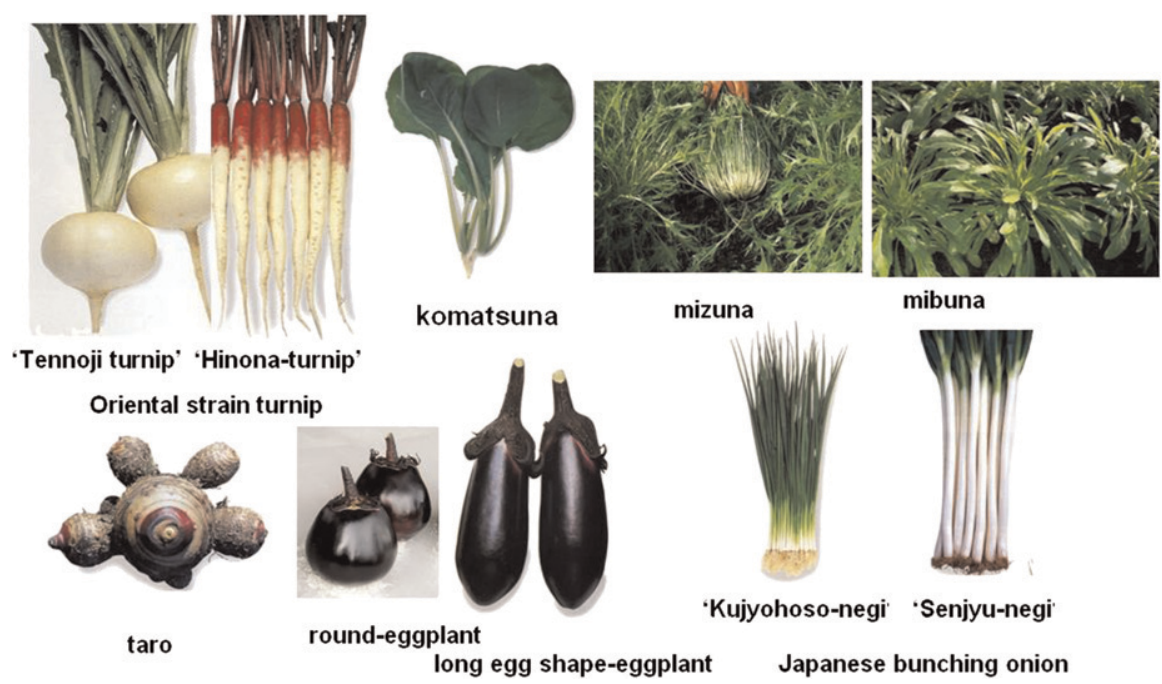

Fig. 3. Variations occurred in different growing conditions. 
Table 5. Nutrition of vegetables indigenous to Japan (wt/100 $\mathrm{g}$ fresh weight).

\begin{tabular}{|c|c|c|c|c|c|c|c|c|c|c|c|}
\hline Vegetable & $\begin{array}{l}\text { Potassium } \\
(\mathrm{mg})\end{array}$ & $\begin{array}{l}\text { Calcium } \\
\text { (mg) }\end{array}$ & $\begin{array}{l}\text { Magnesium } \\
(\mathrm{mg})\end{array}$ & $\begin{array}{c}\text { Phosphorus } \\
\text { (mg) }\end{array}$ & $\begin{array}{l}\text { Iron } \\
(\mathrm{mg})\end{array}$ & $\begin{array}{c}\text { Carotene } \\
(\mu \mathrm{g})\end{array}$ & $\begin{array}{c}\mathrm{B}_{1} \\
(\mathrm{mg})\end{array}$ & $\begin{array}{c}\mathrm{B}_{2} \\
(\mathrm{mg})\end{array}$ & $\begin{array}{l}\text { Niacin } \\
\text { (mg) }\end{array}$ & $\begin{array}{c}\text { Carbon } \\
\text { (mg) }\end{array}$ & $\begin{array}{l}\text { Fiber } \\
(\mathrm{g})\end{array}$ \\
\hline Chive & 330 & 20 & 16 & 86 & 0.7 & 740 & 0.15 & 0.16 & 0.8 & 26 & 3.3 \\
\hline Rakkyo & 230 & 14 & 14 & 35 & 0.5 & 0 & 0.07 & 0.05 & 2.1 & 23 & 21.0 \\
\hline Chinese chive & 510 & 48 & 18 & 31 & 0.7 & 3500 & 0.06 & 0.13 & 0.6 & 19 & 2.7 \\
\hline Goldband lily & 740 & 10 & 25 & 71 & 1.0 & 0 & 0.08 & 0.07 & 0.7 & 9 & 5.4 \\
\hline Japanese bunching onion & 220 & 54 & 18 & 31 & 0.7 & 1900 & 0.05 & 0.09 & 0.5 & 31 & 2.9 \\
\hline Taro & 640 & 10 & 19 & 55 & 0.5 & 5 & 0.07 & 0.02 & 1.0 & 6 & 2.3 \\
\hline Daikon & 230 & 24 & 10 & 18 & 0.2 & 0 & 0.02 & 0.01 & 0.3 & 12 & 1.4 \\
\hline Turnip & 280 & 24 & 8 & 28 & 0.3 & 0 & 0.03 & 0.03 & 0.6 & 19 & 1.5 \\
\hline Eggplant & 220 & 18 & 17 & 30 & 0.3 & 100 & 0.05 & 0.05 & 0.5 & 4 & 2.2 \\
\hline Komatsuna & 500 & 170 & 12 & 45 & 2.8 & 3100 & 0.09 & 0.13 & 1.0 & 39 & 1.9 \\
\hline Mizuna & 480 & 210 & 31 & 64 & 2.1 & 1300 & 0.08 & 0.15 & 0.7 & 55 & 3.0 \\
\hline Japanese butterbur & 330 & 40 & 6 & 18 & 0.1 & 49 & 0 & 0.02 & 0.1 & 2 & 1.3 \\
\hline Japanese hornwort & 500 & 47 & 21 & 47 & 0.9 & 3200 & 0.04 & 0.14 & 0.7 & 13 & 2.3 \\
\hline Water dropwort & 410 & 34 & 24 & 51 & 1.6 & 1900 & 0.04 & 0.13 & 1.2 & 20 & 2.5 \\
\hline
\end{tabular}

Resources council, science and technology, 2005.

European strains are highly tolerant to cold weather and so are grown in the eastern part of Japan.

Komatsuna, komatsuna in Japanese, Brassica rapa L. perviridis group. There are many leaf vegetables in this group of $B$. rapa such as komatsuna and kyona (mizuna and mibuna).

Mizuna and mibuna, mizuna and mibuna in Japanese, Brassica rapa L. japonica group. Approximately 300 years ago (Edo era), mizuna had enlarged turnip-like roots, which were too hard to use. The present mizuna was improved to decrease the size of the root. Also an entire leaf type (mibuna) has been selected from the pinnatisect leaf type (mizuna).

Taro, satoimo in Japanese, Colocasia esculenta. Taro has been cultivated in Japan earlier than the rice cultivation has started. There are three types of corm growth; daughter corm type, daughter and mother corm type, and mother corm type. Not only bulb, but also boiled and dried petioles (zuiki in Japanese) are used.

Eggplant, nasu in Japanese, Solanum melongena. The eggplant cultivation has a long history of more than 12 centuries. Since their introduction to Japan, its growing has spread to all parts of the country and there exist many local cultivars in the Edo era (1615 to 1867). There are many different shapes: small round, round, egg-shaped, long egg-shaped, long, and giant long. As to use, some are used for pickles or boiling and baking.

Japanese bunching onion, negi in Japanese, Allium fistulosum. Japanese bunching onion has also many variations and in east Japan, leaf sheaths are blanched by hilling with soil and blanched sheaths are harvested (white negi). In west Japan, leaf sheaths are grown without hilling and green leaves are harvested (green negi). The difference in the characteristics of japanese bunching onion and the other alliums are explained in the paragraph on asatsuki (Table 3).

\section{PRODUCTION OF VEGETABLES AND NUTRITION}

In root vegetables daikon and taro are the largest in planting area and production (Table 4). In leaf and stem vegetables, japanese bunching onion and komatsuna are the largest in area and production. Eggplant is also important as a fruit vegetable. Table 5 shows the nutrition of some indigenous vegetables. These values are not so different from other vegetables, but chinese chive, komatsuna, japanese hornwort, japanese bunching onion, water dropwort, and mizuna contain high carotene. It is reported that some of these indigenous vegetables contain functional constituents (Nakamura, 2008).

\section{JAPANESE FOOD CULTURE}

The Japanese evaluate the freshness of vegetables, having devised condiments such as miso, soy sauce, and vinegar and also established cooking mainly by means of steam, boiling, simmering, and parboiling. On the other hand, pickled vegetables can be preserved for a long time and so many vegetables have been pickled with vinegar, miso, rice bran, salt, malted rice, mustard, and sake lees. There are two types of pickles in Japan. One is the ordinary pickles, which are pickled with salt (chinese cabbage) or rice bran (daikon). The other is processed pickles, which are pickled with sake lees (daikon, cucumber, and wasabi), malted rice (daikon and chinese cabbage), miso (eggplant, daikon, japanese butterbur, and edible burdock), mustard (eggplant), and vinegar (turnip, daikon and rakkyo) after preliminary pickling with salt. Because our food custom is closely related with seasonal shifts, daily life, ceremonies such as entrance and graduation of school, and weddings and religions, homestyle and officialstyle cooking and tea ceremony dishes have been developed. Different qualities of vegetables have been required for each dish and so many delicate variations in shape, color, smell, and texture have been arranged.

\section{Literature Cited}

Agriculture \& Livestock Industries. 2006. <http:// vegetan.alic.go.jp/yasaijoho/22.htm $>$ [in Japanese].

Aoba, T. 1982. Vegetables in Japan - Fruits vegetables and alliums, Yasaka Shobo, Tokyo [in Japanese].

Aoba, T. 1983. Vegetables in Japan-Leafy and root fruits, Yasaka Shobo, Tokyo [in Japanese].

Jap. Soc. Hort. Sci. 2005. Terminology and plant name in horticulture. Yokendo, Tokyo [in Japanese].

Kumazawa, S. 1953. Combined introduction of olericulture. Yokendo, Tokyo [in Japanese].

Nakamura, Y. 2008. Antimutagenic and anticarcinogenic properties of Kyo-yasai, heirloom vegetables in Kyoto. Genes Environ. $30: 41-47$.

Organizing Committee of JSHS. 1994. Horticulture in Japan. Asakura Publishing Co., Tokyo.

Resources council, science and technology. 2005. Fifth revised and enlarged edition of food composition in Japan. Ministry of Education, Culture, Sports, Science and Technology, Tokyo [in Japanese].

Takashima, S. 1982. Traditional vegetables in Kyoto. Tankosha, Kyoto [in Japanese].

Takashima, S. 2003. Traditional vegetables in Kyoto and seasonal vegetables. Tonbo-shuppan, Osaka [in Japanese].

Vegetable supply stabilization fund. 1997. Vegetables. Kodansha, Tokyo [in Japanese]. 